\title{
Minireview
}

\section{Oxidative Stress Induced in Microorganisms by Zero-valent Iron Nanoparticles}

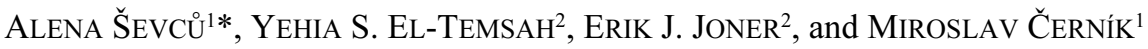 \\ ${ }^{1}$ Institute for Nanomaterials, Advanced Technologies and Innovations, Technical University of Liberec, Studentská 2, \\ 46117 Liberec, Czech Republic; and ${ }^{2}$ Bioforsk Soil and Environment, Fredrik A Dahls vei 20, NO-1432 As, Norway
}

(Received March 28, 2011—Accepted June 28, 2011—Published online July 27, 2011)

\begin{abstract}
Nanoscale zero-valent iron particles (nZVI), with sizes smaller than $100 \mathrm{~nm}$, are promising for environmental remediation of polluted water, soil and sediments. nZVI particles have high potential for migration in the environment and are likely to interact not only with pollutant chemicals but also with living organisms. For these reasons, an environmental concern is rising with respect to unintended effects that need to be weighed against the benefits of remediation. The nZVI particles have a tendency to release electrons and $\mathrm{Fe}^{2+}$. The $\mathrm{Fe}^{2+}$ can convert less reactive hydrogen peroxide to more reactive oxygen species, particularly hydroxyl radicals, via the Fenton reaction. Hydroxyl radicals show strong biochemical activity and can react directly with membrane lipids, proteins and DNA. Reactive oxygen species are normally scavenged by antioxidants and various enzymes; however, elevated concentrations of ROS in microbial cells can result in oxidative stress. Cells under severe oxidative stress show various dysfunctions of membrane lipids, proteins and DNA. This review focuses on the processes resulting in oxidative stress and on up-to-date studies of nZVI-induced intracellular changes leading to such stress in microorganisms.
\end{abstract}

Key words: ecotoxicity, Fenton reactions, ferrous iron, nZVI, reactive oxygen species (ROS)

\section{Introduction}

Nanoscale zero-valent iron (nZVI) has been used increasingly over the last decade to clean up polluted waters, soils and sediments $(15,32,59,62,65,112)$. The nZVI particles reduce toxic chemicals through oxidation of the $\mathrm{Fe}^{0}$ core and subsequent allocation of electrons to the pollutant. For example, contaminants such as polychlorinated hydrocarbons, perchlorate, nitrate, chromate, selenite, chloride and organic dyes can be easily reduced by nZVI to less harmful or stabilized compounds. Effective remediation doses of nZVI range from 1 to $49 \mathrm{~g} \mathrm{~L}^{-1}$ in the peer-reviewed literature $(62,65)$.

However, the unique catalytic properties of nZVI have led to concerns regarding their potential harmful impact on indigenous organisms in the environment where nZVI is released. Microbial communities that carry out crucial functions in soil, water and sediments are among these, and they are relatively easy to assess regarding their negative impact (56).

Recent studies indicate that nZVI is toxic to microorganisms in pure cultures at concentrations as low as a few mg per liter $(5,22,64)$. The mechanisms by which nZVI leads to cell impairment can be divided into two groups: i) direct nanoparticle-cell interactions $(5,67)$ and ii) indirect water/soil chemistry changes $(56,105)$. Here we review current knowledge about the direct mechanism of the nZVI effect on microorganisms.

Nanoparticles attached to the microbial surfaces can decrease both cell mobility and nutrient flow between the cell's exterior and interior compartments (79). Moreover, adsorption of nZVI onto outer cell membranes may lead to

\footnotetext{
* Corresponding author. E-mail: alena.sevcu@tul.cz;

Tel: +420-48535-3786; Fax: +420-48535-3696.
}

increased membrane permeability or even to disruption of the membrane lipid bilayer (64). Furthermore, nZVI might cause rapid generation of free radicals. Redox-active $\mathrm{Fe}^{0}$ reacts with oxygen or water and releases $\mathrm{Fe}^{2+}(112) . \mathrm{Fe}^{2+}$ ions further generate reactive oxygen species (ROS) via Fenton chemistry $(36,51)$. Elevated concentrations of ROS in a cell can result in a situation known as oxidative stress $(19,72)$. Cells under severe oxidative stress show various dysfunctions of membrane lipids, proteins and DNA which could end in apoptosis or death of the microorganisms (19). Hydroxyl radicals have the most deleterious impact on cell viability.

Oxidative stress has existed since oxygen has been produced on the Earth as a byproduct of photosynthesis (72). ROS are generated in substantial amounts in the electron transport chain during normal metabolism in the mitochondria (1). Mitochondrial electron transport reduces $95 \%$ of $\mathrm{O}_{2}$ to water, while the remaining $5 \%$ is reduced to superoxide radicals (43). Dealing with oxidative stress, microorganisms have developed several mechanisms of protection. The prompt response includes production of repair enzymes and antioxidants $(100,103)$. Further, strict regulation of iron assimilation prevents an excess of free intracellular iron that could lead to oxidative stress (101); however, the in situ concentrations of nZVI can be several orders of magnitude higher than the natural iron concentration. Moreover, nZVI particles used in remediation processes have up to a thousand times larger surface area than microscale iron and thus its reactivity is much higher than the reactivity of the forms of iron existing in the environment $(15,65)$.

\section{$n Z V I$ in the environment}

In the environment, iron exists naturally either in the dissolved phase as ferric or ferrous salts or in the solid phase as iron oxides such as goethite and hematite $(55,58)$, while 
$\mathrm{nZVI}$ is a manufactured material with special properties that are advantageous in remediation processes $(59,62,65,112)$.

A major part of the produced nZVI enters the environment through direct injection into polluted soils and aquifers (15, $24,62,105)$. Alternatively, nZVI can be anchored on a solid matrix and used for water, wastewater or gaseous stream treatments (112). As an example, recent results from research on polyethylene glycol-modified nZVI tested for elimination of antibiotics dissolved in water have been promising (32). In the near future, nZVI might thus be used increasingly in municipal wastewater treatment plants to remove pharmaceuticals as well as halogenated organic compounds, pesticides, viruses and other pathogens (32).

Mobility of pristine nZVI particles in the environment is rather limited due to rapid aggregation resulting in micrometer or even larger aggregates (38). In order to effectively treat polluted areas, nZVI particles have been coated with specific polymers, polyelectrolytes and surfactants to increase their mobility and reduce aggregation $(38,39,54,82,90,112)$. Coated nZVI has the potential to reach sites further from the application point, as particle size, particle surface potential, groundwater flow velocity and ionic strength have significant effects on their mobility $(70,87,90)$.

Even though nZVI may be relatively abundant at the remediation site, the amounts of bioavailable iron might be limited, because iron is oxidized and forms soluble ferric oxides and hydroxides sparingly. Nevertheless, $\mathrm{Fe}^{2+}$ and $\mathrm{Fe}^{3+}$ that originate from nZVI might actively or passively $\left(\mathrm{Fe}^{2+}\right.$ only) enter microbial cells (108) or interact with cell wall proteins to affect membrane ionic or electronic transfers directly $(5,95)$.

Characterization of nZVI. Generally, nZVI particles are very reactive and their surface properties change rapidly over time depending on environmental conditions. To protect nZVI particles from rapid oxidation (65), the particle core, which consists of zero-valent iron, is covered by a protective shell $(28,65,74)$. Besides different organic molecules (82), the shell can be formed by $\mathrm{Fe}^{2+}$ and $\mathrm{Fe}^{3+}$ oxides as a result of oxidation. At $\mathrm{pH}<8$, positively charged oxides attract anionic ligands, such as phosphates and sulfates, while at higher $\mathrm{pH}$, the oxide surface becomes negatively charged and can form surface complexes with cations (65).

The basic reaction of $\mathrm{nZVI}$ is Fe oxidation by various species. In the presence of dissolved oxygen, iron is oxidized by a reaction (97):

$$
2 \mathrm{Fe}^{0}+\mathrm{O}_{2}+2 \mathrm{H}_{2} \mathrm{O} \rightarrow 2 \mathrm{Fe}^{2+}+4 \mathrm{OH}^{-} \text {(Eq. 1). }
$$

$\mathrm{Fe}^{2+}$ can be further oxidized to $\mathrm{Fe}^{3+}$ :

$$
4 \mathrm{Fe}^{2+}+4 \mathrm{H}^{+}+\mathrm{O}_{2} \rightarrow 4 \mathrm{Fe}^{3+}+2 \mathrm{H}_{2} \mathrm{O} \text { (Eq. } 2 \text { ) }
$$

which tends to precipitate on the surface of nanoparticles and form ferric oxide or oxohydroxide:

$$
\begin{aligned}
& \mathrm{Fe}^{3+}+3 \mathrm{OH}^{-} \rightarrow \mathrm{Fe}(\mathrm{OH})_{3} \text { (Eq. 3) } \\
& \mathrm{Fe}^{3+}+2 \mathrm{H}_{2} \mathrm{O} \rightarrow \mathrm{FeOOH}+3 \mathrm{H}^{+} \text {(Eq. 4). }
\end{aligned}
$$

In the case of nZVI, which has a large specific surface, the reactions are fast and the result is a strong decrease of dissolved oxygen concentration and subsequent decrease of oxidation reduction potential (ORP). Under anoxic condi- tions, iron can be oxidized by water:

$$
\mathrm{Fe}^{0}+2 \mathrm{H}_{2} \mathrm{O} \rightarrow \mathrm{Fe}^{2+}+\mathrm{H}_{2}+2 \mathrm{OH}^{-} \text {(Eq. 5). }
$$

When the solution $\mathrm{pH}$ is above the isoelectric point of formed mineral phases, the oxide surface becomes negatively charged and can form surface complexes with cations. At low $\mathrm{pH}$, iron oxides are positively charged and attract anionic ligands including key environmental species such as sulfate and phosphate (65). As shown above, nZVI corrodes in the presence of oxygen and water (Eqs. 1 and 5), a process which may be accelerated or inhibited by manipulating the solution chemistry $(85,112)$.

\section{Iron-induced oxidative stress}

Oxidative stress. Oxidative stress is a condition caused by high intracellular concentrations of reactive oxygen species (ROS), which microbial cells are unable to neutralize $(19,26,103)$. ROS includes extremely unstable superoxide radicals, hydroxyl radicals and freely diffusible and relatively long-lived hydrogen peroxide that can all be generated exogenously or intracellularly from various sources. For example, ROS are normally produced during both prokaryotic and eukaryotic metabolism in mitochondria, chloroplasts, peroxisomes or in cytosol, mainly as a by-product of aerobic respiration $(4,72)$. This paradigm has however been doubted by Nohl et al. (80); they argued that ROS generation during respiration has been measured only in vitro in mitochondria using invasive methods. Nohl's group detected ROS only when non-physiological changes in membranes occurred. Undoubtedly, ROS production was initialized primarily by extracellular sources such as UV light or by transition metals, including iron $(46,71,103)$. For example, when nanoparticles of $\mathrm{Fe}_{2} \mathrm{O}_{3}$ were added to a cell culture, ROS levels increased 50 times (68). Interestingly, nanoparticles of $\mathrm{Fe}_{2} \mathrm{O}_{3}$ and soluble microscale $\mathrm{FeCl}_{3}$ caused similar levels of oxidative injury to mussel gills, which could imply that nanoparticles have no special impact on some organisms compared to microscale iron (49); however, the authors (49) did not control the agglomeration of nanoiron oxides, which would increase the actual size of nanoparticles and thus decrease the toxicity (68).

Cells under severe oxidative stress, i.e., exposed to high nZVI concentrations, show various dysfunctions of membrane lipids, proteins and DNA $(19,58)$. Moreover, enhanced ROS generation in mitochondria can initiate the mechanism described as ROS-induced ROS-release. This triggers the opening of mitochondrial channels and can lead to collapse of the mitochondrial membrane potential. The consequence may be temporarily increased ROS generation from the electron transfer chain causing severe cell damage or death $(113,114)$. Thus, aerobic organisms have developed complex defense and repair systems $(31,42)$. In addition, the majority of microorganisms have strict regulation of iron assimilation to prevent excess free intracellular iron $(78,101)$. It should be pointed out that ROS are also beneficial as secondary messengers in intracellular signaling, e.g., as regulators during cell differentiation and for maintaining homeostasis $(1,12,29)$.

The role of $n Z V I$ in Fenton chemistry. nZVI can react 
with either water or oxygen to produce ferrous iron (Eqs. 1 and 5) (51). Both redox reactions can occur in an environment where nZVI is applied or directly in eukaryotic microorganisms. The latter situation is possible because nZVI can be actively internalized via endocytosis $(91,106)$.

Redox-active iron that is generated from nZVI particles may enhance the generation of more highly reactive hydroxyl radicals from less reactive hydrogen peroxide via Fenton chemistry in microbial cells (Fig. 1, Eq. 6) $(27,36)$.

$$
\mathrm{Fe}^{2+}+\mathrm{H}_{2} \mathrm{O}_{2} \rightarrow \mathrm{Fe}^{3+}+\mathrm{OH}+\mathrm{OH}^{-} \text {(Eq. 6) }
$$

Ferrous iron could be oxidized to ferric iron and then be available to react with superoxide radicals and start the reaction again (Eqs. 7 and 8 ).

$$
\begin{aligned}
& \mathrm{Fe}^{2+}+\mathrm{OH} \cdot \rightarrow \mathrm{Fe}^{3+}+\mathrm{OH}^{-} \text {(Eq. 7) } \\
& \mathrm{Fe}^{3+}+\mathrm{O}_{2}^{-} \cdot \rightarrow \mathrm{Fe}^{2+}+\mathrm{O}_{2} \text { (Eq. 8) }
\end{aligned}
$$

Ferric iron could also react with peroxide radicals to form superoxide radical (Eq. 9).

$$
\mathrm{Fe}^{3+}+\mathrm{H}_{2} \mathrm{O}_{2} \rightarrow \mathrm{Fe}^{2+}+\mathrm{OOH} \cdot+\mathrm{H}^{+} \rightarrow \mathrm{Fe}^{2+}+2 \mathrm{H}^{+}+\mathrm{O}_{2}^{-} \cdot \text { (Eq. 9) }
$$

When $\mathrm{H}_{2} \mathrm{O}_{2}$ is in excess, the $\mathrm{Fe}^{2+}$ generated as in Eq. 9 can enter the Fenton reaction (Eq. 6) and produce more ROS (40). Also, superoxide radicals can liberate $\mathrm{Fe}^{2+}$ from ferritin, an intracellular iron-storage protein (88), or other similar proteins that contain $[4 \mathrm{Fe}-4 \mathrm{~S}]^{2+}$ clusters which favor Fenton chemistry $(30,101)$. In addition, the Fenton reaction is triggered by NADH by reloading $\mathrm{Fe}^{2+}$ from $\mathrm{Fe}^{3+}$ (Fig. 1) (44).

\section{Cell damage initiated by $\mathrm{nZVI}$ and ROS}

We now turn to the deleterious effect of higher concentrations of nZVI and ROS induced by iron. The nZVI might indirectly generate ROS that damage iron-sulfur groups, cofactors in many enzymes, leading to Fenton chemistry that catalyzes the production of more ROS. Consequently, generated ROS can be released into the cytosol and trigger ROS-induced ROS-release in other mitochondria, potentially leading to cellular injury and death $(113,114)$. Although this phenomenon has been described for mammalian cells, it is likely that a similar mechanism also occurs in microorganisms. Besides these effects, elevated ROS levels may be a stress signal that activates redox-sensitive signaling pathways, which may have either a harmful or a protective function (16).

Lipid peroxidation. ROS can initiate lipid peroxidation, which begins by the removal of hydrogen from an unsaturated fatty acid chain. The resulting fatty acid radical may react with oxygen to generate lipid peroxyl radicals that further propagate the chain reaction of lipid peroxidation $(37,99)$. Thus, a single initiation can result in the conversion of hundreds of fatty acids to lipid hydroperoxides. It has been well established that when redox-active iron is added to membrane homogenate in vitro, the peroxidation is much faster, because more radicals are generated via the Fenton reaction (Eq. 6). Vulnerability of a membrane to lipid peroxidation is increased by polyunsaturated lipids, especially when present in chloroplasts (63).

Peroxidized membranes lose selective permeability and, under extreme conditions, can lose their integrity. The lipid peroxidation product, lipid hydroperoxide, can decompose into several radical species that are able to react with DNA and cause the formation of a modified base, which can induce mutations (111). Water-soluble lipid peroxidation products (e.g., aldehydes) can diffuse from membranes into cytosol and other cellular compartments. Dialdehydes can act as cross-linking reagents and cause protein aggregation. Notably, lipid peroxidation products may inhibit various enzymes. Thus, the process of lipid peroxidation, and its products, can be seriously harmful to cell viability.

Protein oxidation. More than a century ago, H.D. Dakin published the first studies on the oxidation of protein constituents-amino acids, in addition to other mechanisms, by Fenton chemistry $(17,18)$. Dakin was successful in finding various products of the action of hydrogen peroxide on different amino acids.

More recent studies showed that iron-catalyzed protein oxidation is a site-specific process, which can occur only at

\section{bacterial cell}

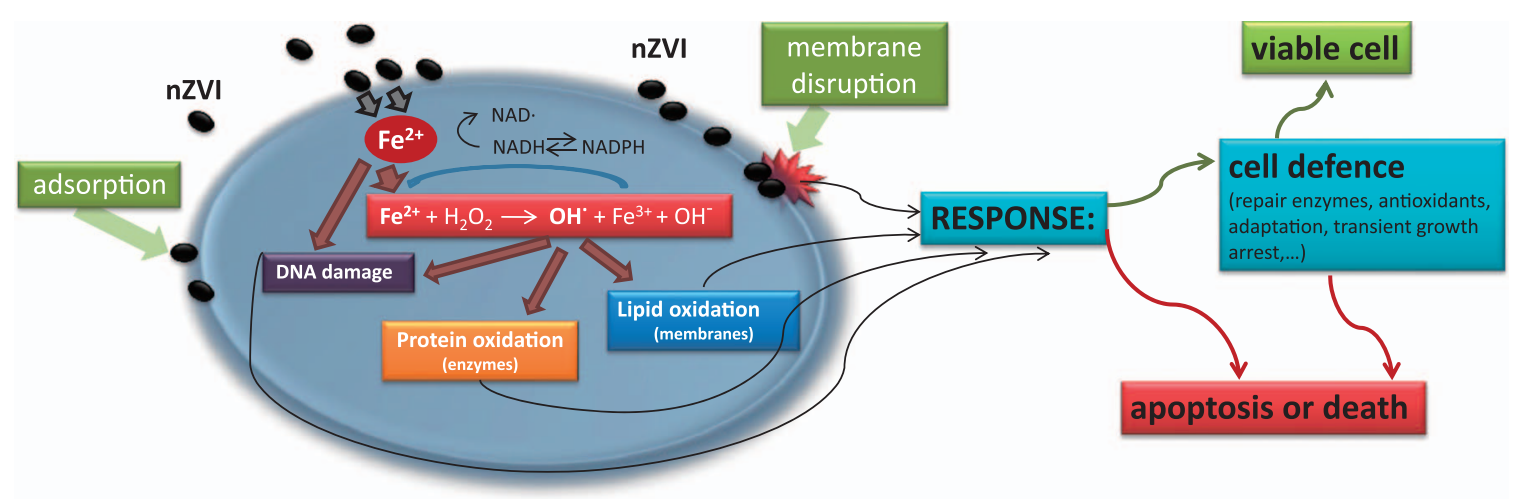

Fig. 1. Examples of potential cell damage and response after exposure to nZVI. Fe ${ }^{2+}$, released from nZVI, is able to cross the membrane either via active cellular uptake or leakage through sites with reduced membrane integrity. Oxidative damage is primarily caused by highly reactive hydroxyl radicals resulting from $\mathrm{Fe}^{2+}$ reaction with hydrogen peroxide. $\mathrm{Fe}^{3+}$ could be reduced by $\mathrm{NADH}$ and therefore regenerate $\mathrm{Fe}{ }^{2+}$. OH. radicals might damage DNA, proteins and lipids. $\mathrm{Fe}^{2+}$ can also harm DNA directly. Adapted from (40). 
iron binding sites of the protein (e.g., on histidine, cysteine, lysine, and methionine). $\mathrm{Fe}^{2+}$, resulting from the direct reduction of $\mathrm{Fe}^{3+}$ (for example Eqs. 6, 8, and 9), can bind to a metal-binding site and react with hydrogen peroxide to generate ROS, which further react with the side chains of amino acid residues (96). This reaction system is called "metal-ion-catalyzed oxidation systems" and is like Fenton chemistry involving hydrogen peroxide. Metal-ion-catalyzed damage to membranes can affect proteins and lipids in parallel.

Moreover, proteins may cross-link with one another or form hydrophobic bonds. Oxidative protein damage could also affect the activity of DNA repair enzymes and cause DNA-protein cross-linking (20). Further, ROS can lead to the formation of disulfide bonds between sulfur-containing amino acids, thus disturbing the structure and function of the protein. Also, mitochondria or chloroplasts exposed to ROS lose ion balance and similarly, electron-transport chain proteins could be damaged.

DNA oxidation and mutation. Exposure of cells to redox active iron and subsequent enhanced ROS generation via Fenton chemistry cause both DNA and RNA damage (26, $40,48)$. It appears that mitochondrial DNA is more sensitive than nuclear DNA to oxidative damage due to its proximity to the main source of oxidant generation. The most dangerous are hydroxyl radicals, which are able to attack the base and saccharide moiety of DNA, which leads to saccharide fragmentation and strand breaks $(44,75)$. Strand breaks are more dangerous and even more lethal to cells than base damage, although the latter can lead to various mutations (26).

However, a significant amount of DNA damage appears not to be due to hydroxyl radicals but Fenton oxidants produced on $\mathrm{Fe}^{2+}$ atoms associated with DNA $(40,53,75)$. DNA-bound $\mathrm{Fe}^{3+}$ may interact with reducing DNA radicals to oxidize DNA, while in the presence of oxygen, DNA peroxyl radicals are formed and react with $\mathrm{Fe}^{2+}$.

To date, two different groups of iron-mediated Fenton oxidants of DNA have been found and characterized by specific sites of DNA cleavage (40). ROS attack of DNA bases leads to about 50 base alterations. For example, thymine and guanine residues in DNA can be hydroxylated or oxidatively degraded $(10,21)$. Thymine glycol, a product of thymine oxidation (thymine residues are more sensitive than other residues), can block replication by DNA polymerase and harm transcription by making RNA polymerase stop at or near the site of the lesion or can cause misreading (10).

\section{Intracellular defense-repair system under oxidative stress}

In general, microorganisms have developed two principal strategies for oxidative damage defense. The first includes antioxidant enzymes such as superoxide dismutases (SOD), glutathione peroxidases, catalases, and non-enzymatic low molecular mass molecules that include ascorbate, pyruvate, flavonoids, carotenoids and glutathione $(73,89,107)$. The second strategy of defense is based on repair enzymes which remove and/or repair oxidatively damaged macromolecules (14). Both defense strategies are induced at the lowest level of oxidative stress. During higher levels of oxidative stress, the protective response shifts to a pro-inflammatory response which induces redox-sensitive signaling pathways. At the highest level, injury to the electron transfer chain and mitochondrial membranes could lead to acute toxicity and cell apoptosis $(77,109)$.

Antioxidants and repair enzymes. The most important in the cell protection system is SOD. Superoxide dismutation speeds the conversion of superoxide to $\mathrm{H}_{2} \mathrm{O}_{2}$, which is further reduced to water by catalases and glutathione peroxidases. Moreover, SOD prevents the accumulation of free $\mathrm{Fe}^{2+}$. All members of the SOD family utilize transition metals at their active sites as cofactors, e.g., mononuclear $\mathrm{Fe}, \mathrm{Mn}, \mathrm{Ni}$ and dinuclear CuZn $(3,11,19,107)$. Specific SOD isoforms are induced by its substrate, which could serve as an indicator of oxidative stress in a particular cell compartment. For example, Fe-SOD is localized in chloroplasts while Mn-SOD is found in mitochondria where superoxide radicals are generated (57).

Catalases are divided into three groups. Manganese catalases have been found only in prokaryotes. Catalase peroxidases act as both catalases and peroxidases and have been detected in prokaryotes and some eukaryotes. Classical catalases (cat) contain heme groups and convert $\mathrm{H}_{2} \mathrm{O}_{2}$ to $\mathrm{H}_{2} \mathrm{O}$ and $\mathrm{O}_{2}$ in a two-step process (76). First, one molecule of $\mathrm{H}_{2} \mathrm{O}_{2}$ is reduced to water and the $\mathrm{Fe}^{3+}$ of the catalase is converted to cat $(\mathrm{Fe}[\mathrm{V}] \mathrm{O})$. Second, the cat $(\mathrm{Fe}[\mathrm{V}] \mathrm{O})$ molecule is converted back to $\mathrm{Fe}^{3+}$ while another molecule of $\mathrm{H}_{2} \mathrm{O}_{2}$ is reduced to $\mathrm{H}_{2} \mathrm{O}$ and $\mathrm{O}_{2}$. Classical catalases have been found widely in eukaryotes, but also in some prokaryotes.

Reduced ubiquinone is able to scavenge lipid peroxyl radicals in addition to superoxide and peroxide radicals, and thus prevent a chain reaction causing oxidative damage to lipids (94). Moreover, carotenoid staphyloxantin is important for lipid protection, because it can scavenge ROS in the cell membrane (13). Staphyloxantin located in the cell membrane was reported from Staphylococcus aureus cultures (13). Flavonoids are able to inhibit lipid peroxidation and, what is more important, scavenge metal ions (84).

Glutathione and phytochelatins, low molecular weight peptides, are intracellular metal complexing ligands (60). Glutathione is produced by bacteria, algae, plants and animals, while phytochelatins are produced by algae, fungi and plants. They can specifically respond to various metals and are linked to metal detoxification (50). Glutathione is protective against oxidative damage and regulates redox potential for amino acids and proteins.

Because redox active $\mathrm{Fe}^{2+}$ catalyzes the Fenton reaction and hydroxyls radical generation, free iron must be quickly incorporated into ferritin, iron-sulfur clusters, transferrin, siderophores, or heme groups to prevent oxidative damage $(9,35,45,102)$. For example, ferritins are able to store about 4,500 iron atoms per complex. Furthermore, Dps proteins and Dps-like proteins, which are to a certain extent homologous to ferritin, can sequester both $\mathrm{Fe}^{2+}$ and $\mathrm{H}_{2} \mathrm{O}_{2}$ and avoid the creation of hydroxyl radicals during the Fenton reaction in an archaebacterium Pyrococcus furiosus (86). In bacteria, a Dps-like bacterioferritin, Orf4, protect cells through iron sequestration (103). Some prokaryotes have the iron-dependent repressor Fur (ferric uptake regulator), which represses the transcription of a number of iron uptake transporters once intracellular iron becomes high $(41,102)$. 
Hydroxide radical attack can be stopped nonenzymatically. Histones and the compact structure of chromatin protect the DNA from $\mathrm{OH}^{\cdot}$ attack and from iron binding. Moreover, Dps protein binds DNA and forms very stable complexes so as to prevent strand breaks and base damage in prokaryotes (75). Further, Orf4 defends DNA against oxidative damage via DNA binding in a non-specific manner (103).

Bacillus subtilis use nitric oxide for protection against oxidative stress (34). Nitric oxide can suppress the Fenton reaction by inhibiting cysteine reduction of ferric iron. Cysteine is the main reducing agent that drives the Fenton reaction in Escherichia coli (81) as well as in B. subtilis. Moreover, nitric oxide boosts the activity of catalase, which is an iron-heme enzyme involved in $\mathrm{H}_{2} \mathrm{O}_{2}$ scavenging. Nitric oxide thus helps to maintain redox homeostasis and protect the cell during rapid metabolic changes. To date, bacterial nitric oxide synthases have been found only in Gram-positive bacteria (34).

Also, relatively high concentrations of $\mathrm{Mn}^{2+}$ ions in Deinococcus radiodurans and Lactobacillus plantarum possibly serve as antioxidants $(33,41)$. Manganese complexes can catalyze the removal of hydrogen peroxide and can scavenge superoxide radicals.

\section{nZVI toxicity}

Despite increasing use of nZVI materials and their potential toxic influence on both water and soil organisms, information on nZVI-induced oxidative stress within bacteria, fungi and other organisms is rather scarce. Studies of the nZVI effect on several groups of organisms, such as cyanobacteria, algae, arthropods and invertebrates, have so far not appeared in the literature.

Bacteria. Recently, Auffan et al. (5) examined the effect of 1-hour exposure of a wild-type and a mutant bacterium E. coli to nanoparticulate $\mathrm{Fe}_{2} \mathrm{O}_{3}, \mathrm{Fe}_{3} \mathrm{O}_{4}$ and nZVI (Table 1). Transmission electron microscopy showed morphological changes of bacterial cells, and also changes of the nZVI shape (Fig. 2). The nZVI was probably oxidized to iron oxyhydroxides and remained adsorbed on the cell surface, but did not enter the cells of E. coli. Nanoparticulate $\mathrm{Fe}_{2} \mathrm{O}_{3}$ did not harm the wild type, but was toxic to the mutant that lacked antioxidant enzymes SOD. Further, nanoparticulate $\mathrm{Fe}_{3} \mathrm{O}_{4}$ and nZVI showed toxic effects also in the wild type at concentrations of 700 and $70 \mathrm{mg} \mathrm{L}^{-1}$, respectively. The highest toxicity was thus observed for nZVI. The authors suggested that nanoparticles might cause oxidative stress via ROS generation and the Fenton reaction, as demonstrated using a mutant strain of $E$. coli without protective SOD enzymes. Oxidative stress in $E$. coli can result from disturbance of the electronic and/or ionic transport chains

Table 1. Summary of current studies on nZVI effect on various microorganisms, predominantly bacteria

\begin{tabular}{|c|c|c|c|c|c|c|c|c|}
\hline Organism & Nanoiron form & $\begin{array}{l}\text { Particle } \\
\text { size } \\
{[\mathrm{nm}]}\end{array}$ & $\begin{array}{l}\text { Incubation } \\
\text { length }\end{array}$ & $\begin{array}{l}\text { Oxidative } \\
\text { stress }\end{array}$ & Other toxic effects & $\begin{array}{c}\text { Highest } \\
\text { nZVI } \\
\text { concentration } \\
\text { tested } \\
{\left[\mathrm{mg} \mathrm{L}^{-1}\right]}\end{array}$ & $\begin{array}{l}\text { Effective } \\
\text { dose } \\
{\left[\mathrm{mg} \mathrm{L}^{-1}\right]}\end{array}$ & Reference \\
\hline \multicolumn{9}{|l|}{ Bacteria } \\
\hline $\begin{array}{l}\text { Alcaligenes } \\
\text { eutrophus }\end{array}$ & $\mathrm{nZVI}$ & n.d. ${ }^{\mathrm{a}}$ & $1-9 \mathrm{~d}$ & n.d. & $\begin{array}{l}\text { decrease in total RNA } \\
\text { content, strongest effect }\end{array}$ & 560 & 560 & An et al. (2) \\
\hline A. eutrophus & $\begin{array}{l}\text { sodium oleate } \\
\text { nZVI }\end{array}$ & n.d. & $1-9 \mathrm{~d}$ & n.d. & $\begin{array}{l}\text { decrease in total RNA } \\
\text { content, lowest effect }\end{array}$ & 560 & 560 & An et al. (2) \\
\hline A. eutrophus & chitosan nZVI & n.d. & $1-9 \mathrm{~d}$ & n.d. & $\begin{array}{l}\text { decrease in total RNA } \\
\text { content, lower effect }\end{array}$ & 560 & 560 & An et al. (2) \\
\hline $\begin{array}{l}\text { Bacillus subtilis } \\
\quad \text { var. niger }\end{array}$ & nZVI & $20-30$ & $5 \mathrm{~min}$ & + & nZVI cell adsorption, ROS & 10,000 & 100 & Diao and Yao (22) \\
\hline Dehalococcoides spp. & $\mathrm{nZVI}$ & n.d. & $21 \mathrm{~d}$ & n.d. & nZVI cell adsorption & 1,000 & 1,000 & Xiu et al. (110) \\
\hline Escherichia coli & nZVI & 50 & $1 \mathrm{~h}$ & + & nZVI cell adsorption & 700 & 70 & Auffan et al. (5) \\
\hline E. coli & $\mathrm{nZVI}$ & $<100$ & $1 \mathrm{~h}$ & + & $\begin{array}{l}\text { nZVI cell adsorption, cell } \\
\text { membrane disruption }\end{array}$ & 110 & $>60$ & Lee et al. (64) \\
\hline E. coli & $\begin{array}{l}\text { polystyrene } \\
\text { sulfonate nZVI }\end{array}$ & $\begin{array}{l}40-60+ \\
\sim 67\end{array}$ & $1-12 \mathrm{~h}$ & n.d. & - & 1,000 & - & Li et al. (67) \\
\hline E. coli & $\mathrm{nZVI}$ & $40-60$ & $1-12 \mathrm{~h}$ & n.d. & $\begin{array}{l}\text { nZVI cell adsorption, cell } \\
\text { inactivation }\end{array}$ & 1,000 & 5 & Li et al. (67) \\
\hline $\begin{array}{r}\text { Pseudomonas } \\
\text { fluorescens }\end{array}$ & $\mathrm{nZVI}$ & $20-30$ & $5 \mathrm{~min}$ & + & nZVI cell adsorption, ROS & 10,000 & 100 & Diao and Yao (22) \\
\hline $\begin{array}{l}\text { River bacterial } \\
\text { community }\end{array}$ & $\mathrm{nZVI}$ & $30-90$ & $1-36 \mathrm{~d}$ & n.d. & $\begin{array}{l}\text { initial decrease in bacterial } \\
\text { diversity }\end{array}$ & 100 & 100 & Barnes et al. (8) \\
\hline $\begin{array}{l}\text { Groundwater } \\
\text { bacterial community }\end{array}$ & nZVI & $30-90$ & $1-200 \mathrm{~d}$ & n.d. & $\begin{array}{l}\text { inhibition of biodegrada- } \\
\text { tion, decrease in cell } \\
\text { number }\end{array}$ & 1,000 & 300 & Barnes et al. (9) \\
\hline $\begin{array}{l}\text { Sulfate reducing bacteria, } \\
\text { methanogens, and } \\
\text { eubacteria }\end{array}$ & $\mathrm{nZVI}$ & $\sim 100$ & $250 \mathrm{~d}$ & n.d. & - & $1,500-100$ & - & $\begin{array}{l}\text { Kirschling et al. } \\
\text { (56) }\end{array}$ \\
\hline \multicolumn{9}{|l|}{ Fungi } \\
\hline $\begin{array}{l}\text { Aspergillus } \\
\text { versicolor }\end{array}$ & $\mathrm{nZVI}$ & $20-30$ & $5 \mathrm{~min}$ & - & - & 10,000 & - & Diao and Yao (22) \\
\hline
\end{tabular}

a not done 


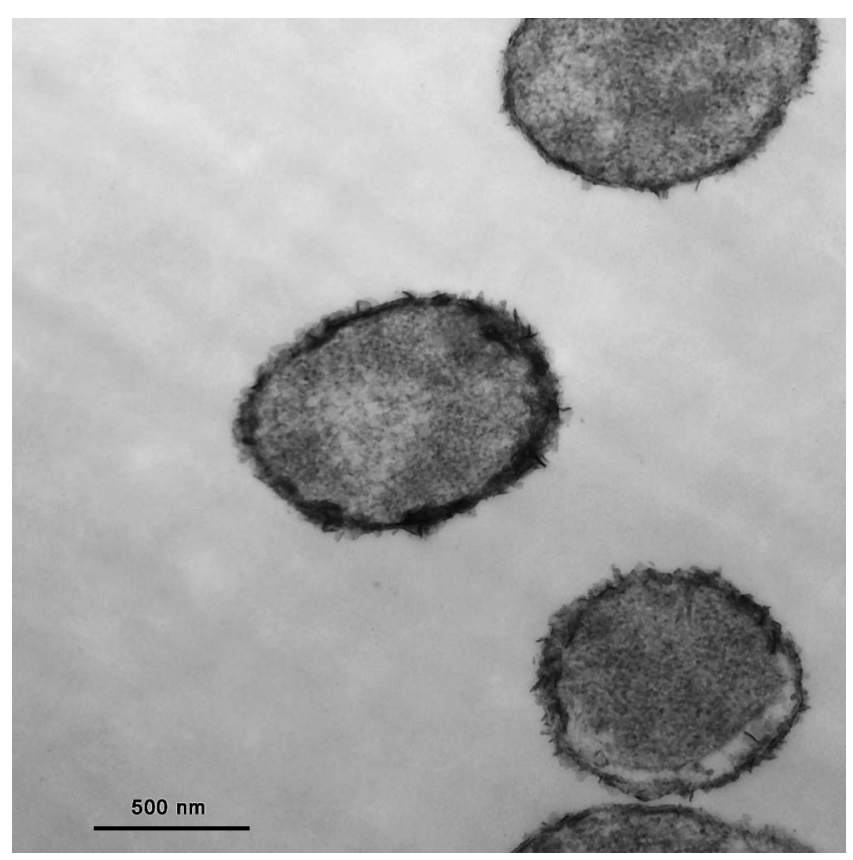

Fig. 2. Transmission electron microscopy images of $E$. coli incubated with $100 \mathrm{mg} \mathrm{L}^{-1}$ of nZVI. Nanoparticles are clearly visible adsorbed on the $E$. coli cell wall. nZVI changed shape from pseudospherical to lamellar, which might be $\mathrm{Fe}^{3+}$ oxide-hydroxides. Iron nanoparticles were not found in the cells. Photo copyright Melanie Auffan.

due to the strong affinity of the nanoparticles for the cell membrane (5). Similar results of nZVI toxicity on E. coli have been described by Lee et al. (64). The highest toxicity of nZVI was found under anaerobic conditions. In the presence of oxygen, nZVI showed lower toxicity. Significant inactivation of $E$. coli was detected at nZVI concentrations above 60 and $70 \mathrm{mg} \mathrm{L}^{-1}$ under de-aerated and aerated conditions, respectively. Under aerated conditions, nZVI oxidizes and resulting precipitates on the surface reduce nZVI reactivity and thus cause lower toxicity. Under anaerobic conditions, $\mathrm{Fe}^{2+}$ formed at the surface of nanoparticles can contribute to ROS production because $\mathrm{Fe}^{2+}$ is not rapidly oxidized to $\mathrm{Fe}^{3+}$. $\mathrm{Fe}_{2} \mathrm{O}_{3}$ nanoparticles were not toxic to $E$. coli at concentrations of $9 \mathrm{mg} \mathrm{L}^{-1}$ and microscale ZVI was not toxic at concentrations as high as $1 \mathrm{~g} \mathrm{~L}^{-1}$. Cell membranes were visibly disrupted by nZVI (Fig. 3). Iron, as a strong reductant, might induce the decomposition of functional groups in membrane proteins and lipopolysaccharides, or nZVI could be oxidized by intracellular oxygen, leading to oxidative damage via the Fenton reaction. When nZVI penetrates cells through disrupted membranes, it causes further physical damage and death (64). Effects of pristine $\mathrm{nZVI}$ and polystyrene sulfonate and polyaspartate polymers or natural organic matter coating on nZVI in E. coli culture were examined by Li et al. (67). Pristine nZVI showed an inhibitory effect on bacteria at concentrations of $5 \mathrm{mg} \mathrm{L}^{-1}$. When applied under aerated conditions, the toxic effect was lower than under anaerobic conditions. This result was predictable because nZVI oxidizes under aerobic conditions. Natural organic matter coating and polymers decreased the toxicity of nZVI significantly, probably due to a thick layer formed by the polymer preventing adhesion to the cell surface.

Xiu et al. (110) found that the anaerobic dechlorinating

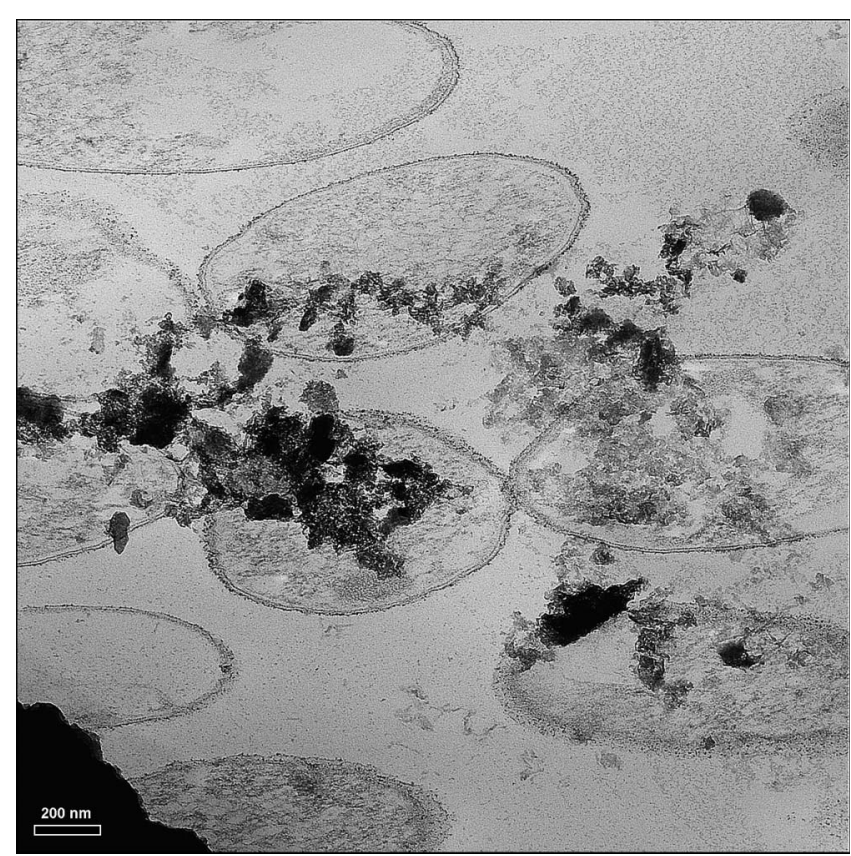

Fig. 3. Transmission electron microscopy images of $E$. coli treated with $110 \mathrm{mg} \mathrm{L}^{-1}$ of $\mathrm{nZVI}$ at $\mathrm{pH} 8.0$, incubation time $30 \mathrm{~min}$. Membrane disruption and cytosol leakage are clearly visible as well as dark spots of $\mathrm{Fe}^{3+}$ oxide-hydroxides. Photo copyright Jeyong Yoon.

bacteria Dehalococcoides spp. was sensitive to nZVI exposure when they studied the bioremediation of trichloroethylene using a mixture of bacterial species. The authors expected biostimulation of Dehalococcoides spp. and methanogenic bacteria driven by the addition of $1 \mathrm{~g} \mathrm{~L}^{-1}$ of nZVI. While methanogens were positively affected, Dehalococcoides spp. was inhibited, as measured by the rate of dechlorination. Using transmission electron microscopy, iron nanoparticles were observed being adsorbed on the bacterial cell surface, but not intracellularly. It was suggested that nZVI adsorption on the cell might cause impairment of membrane functions which could result in cell death. Nevertheless, Dehalococcoides spp. and its dechlorination activity recovered after about $300 \mathrm{~h}$ of incubation. This might be due to nZVI oxidation and complexation with mineral salts (110). Another batch experiment was performed by An et al. (2) using an Alcaligenes eutrophus culture and comparing the effects of pristine nZVI with those of chitosan-coated nZVI and sodium oleate-coated nZVI (2). The objective was to measure denitrification rate under different nZVI treatments to enhance the activity of denitrifying bacteria. Besides this, these authors detected a higher content of total RNA in samples with coated nZVI compared to pristine nZVI, and concluded that coated nZVI might be less toxic to bacteria than unmodified nZVI (2). A negative effect of $100 \mathrm{mg} \mathrm{L}^{-1}$ nZVI on a bacterial community enclosed in microcosms with river water was detected after one day in a 36-day experiment (8). The changes in bacterial community composition were highest between day 0 and 1 (Sørenson index 64.3 $\pm 7.5 \%$ ); however, the community recovered to initial richness. Also $\mathrm{pH}$, oxidation-reduction potential and dissolved oxygen concentration changes were temporary and returned to pretreatment values during the 36 days of the experiment. The 
authors concluded that the bacterial community structure was not disturbed by nZVI nanoparticles. Similar results on the effects of nZVI on bacterial populations were recently published by Kirschling et al. (56). The addition of nZVI and surface-modified nZVI did not negatively influence bacterial abundance in the studied microcosms. Moreover, surface-modified nZVI even increased bacterial populations. Still, nZVI to some extent influenced microbial composition; several bacterial groups were eliminated while others increased, such as sulfate reducers and methanogens. The positive stimulation of both latter groups might be beneficial for in situ bioremediation techniques. On the other hand, Barnes et al. (7) found negative effects of nZVI on the biodegradation of chlorinated hydrocarbons in microcosms with dechlorinating and sulfate-reducing groundwater bacteria. Biodegradation was completely inhibited in both groups of anaerobic groundwater bacteria at nZVI concentrations above $0.3 \mathrm{~g} \mathrm{~L}^{-1}$ and, moreover, viable cell counts declined (7). Concentrations below $0.1 \mathrm{~g} \mathrm{~L}^{-1}$ had no significant impact on viable cell counts; however, the biodegradation was hindered. It was suggested that bacterial biodegradation could be applied after nZVI treatment, but not simultaneously.

Algae. Elevated production of ROS constitutes a particularly severe risk to photosynthetic organisms such as cyanobacteria and algae, because photosynthesis is an important source of superoxide radicals (84).

In the rare situation when bioavailable iron is in excess, it might induce oxidative stress, which affects algal growth and has a negative impact on natural phytoplankton. Estevez et al. (25) studied the effect of surplus redox-active iron on oxidative stress in Chlorella vulgaris. When culture medium was supplemented with $500 \mu \mathrm{M}$ iron, the cells showed elevated levels of membrane lipid peroxidation and other oxidative stress signs. In addition, the morphology of $C$. vulgaris was affected, probably due to harmful effects of ROS on photosynthesis. On the other hand, the C. vulgaris culture was able to adapt to mild oxidative stress by the production of antioxidants, particularly $\alpha$-tocopherol, ascorbate and thiols (25). Similarly, the unicellular freshwater alga Euglena gracilis was able to respond to increasing $\mathrm{FeSO}_{4}$ loads by increasing the total antioxidant activity that scavenged most of the generated hydroxyl radicals (47). It is likely that nZVI can show similar or stronger effects on algae than microscale iron due to their higher specific surface area; however, such studies are yet to be published.

Kobayashi et al. (61) examined the possible function of $\mathrm{Fe}^{2+}$ as a ROS generator in the unicellular green alga Haematococcus pluvialis. Addition of $450 \mu \mathrm{M} \mathrm{Fe}^{2+}$ enhanced the formation of hydroxyl radicals in the cells via the Fenton reaction. $H$. pluvialis responded by producing the carotenoid antioxidant astaxanthin, which was localized in cytosolic lipid bodies. With excess addition of $600 \mu \mathrm{M} \mathrm{Fe}^{2+}$, carotenoid formation was reduced, probably due to severe ROS injuries (66).

Short-term exposure of the unicellular green alga Chlamydomonas reinhardtii to selected metals caused elevated ROS production (98). Iron was added at several environmentally relevant concentrations that did not directly affect photosynthesis in C. reinhardtii. On the other hand, iron induced maximal ROS production among the redox- active metals studied; the order of ROS-inducing capacity being: $\mathrm{Fe}^{3+}>\mathrm{Ag}^{+}>\mathrm{Cu}^{2+}>\mathrm{Cr}^{6+}$.

Microscopic fungi. Nanoparticles might have direct and indirect effects on fungi. Only one experiment on the direct effects of nZVI on fungi, using Aspergillus versicolor, has been published to date (22). The authors tested the capacity of nZVI to inactivate bacteria and A. versicolor. Even when the fungal culture was treated with a relatively high concentration of nZVI, the effect on its viability was zero (Table 1). Possible explanations for this might be the very short exposition time; the fungus had been in contact with nZVI for only five minutes. Moreover, cell walls of fungi are composed mainly of polysaccharides such as chitin and glucan that efficiently protect the cells against unfavorable environments.

Regarding indirect effects, symbiotic fungi or bacteria may be harmed by nanoparticles as parts of mycorrhizas and lichens, which may cause reduced nutrient availability for plants (79). Mycorrhizal fungi can protect host plants against oxidative stress (92), but this beneficial role might be affected by nanoparticles. In experiments with the application of nZVI to soil prior to or during the growth of mycorrhizal plants (ryegrass and clover), rates of $250 \mathrm{mg} \mathrm{kg}^{-1}$ with $0.25 \%$ PAA (i.e., $25 \mathrm{~mL} \mathrm{~kg}^{-1}$ of a $10 \mathrm{~g} \mathrm{~L}^{-1} \mathrm{nZVI}$ suspension) resulted in severe reduction $(30-50 \%)$ in plant growth without mycorrhiza being able to alleviate the stress or toxicity caused by nZVI (Fig. 4; El-Temsah and Joner, unpublished data). Such stress alleviation by mycorrhizas is commonly observed with other abiotic stressors (93). The negative effects were possibly due to the low redox potential of the nZVI solution added, as boron from synthesis using $\mathrm{BH}_{4}$ had been washed out and was not contributing to the adverse effects.

Other organisms. Direct effects on plants have been quantified, indicating that fresh $\mathrm{nZVI}$ has $\mathrm{EC}_{50}$ values between 300 and $1,200 \mathrm{mg} \mathrm{kg}^{-1}$ for three common agricultural plants (barley, ryegrass and flax), with a substantial influence of soil texture. $\mathrm{EC}_{50}$ values in sandy soil were thus less than half of those found in clay soil (23).

Ecotoxicity data for nZVI on terrestrial macro- and mesofauna are only just starting to emerge. Our own preliminary studies have shown that, e.g., earthworms are

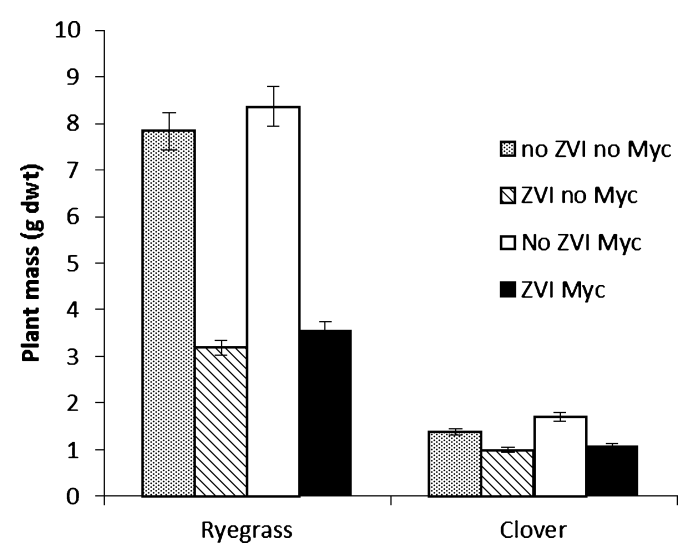

Fig. 4. Plant biomass of 6-week-old ryegrass and clover grown in sandy soil with added $25 \mathrm{~mL} \mathrm{~kg}^{-1}$ of nZVI $\left(10 \mathrm{~g} \mathrm{~L}^{-1}\right)$ after 3 weeks, and the effect of pre-established arbuscular mycorrhiza (Myc). Bars are $\operatorname{SEM}(n=3)$. 
sensitive to $\mathrm{nZVI}$ concentrations of $\geq 100 \mathrm{mg} \mathrm{kg}^{-1}$. Both the compost worm Eisenia fetida, used in standardized OECD tests on soil toxicity, and the epigeic earthworm Lumbricus rubellus showed signs of adverse effects during long-term exposure to $100 \mathrm{mg} \mathrm{nZVI} \mathrm{kg}{ }^{-1}$, whereas acute (mortality after $14 \mathrm{~d}$ exposure in sandy soil) toxicity was observed only at concentrations $\geq 500 \mathrm{mg} \mathrm{nZVI} \mathrm{kg}{ }^{-1}$ for both species (El-Temsah and Joner, unpublished results). In comparison, the springtail Folsomnia candida seem more tolerant than earthworms, with a mortality rate in acute toxicity tests of

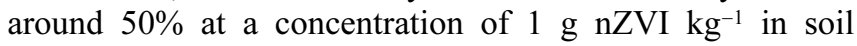
(El-Temsah and Joner, unpublished data).

\section{Summary}

The direct effects of nZVI addition have been studied on the bacteria Alcaligenes eutrophus, Bacillus subtilis var. niger, Dehalococcoides spp., Escherichia coli, Pseudomonas fluorescens, river and groundwater bacterial assemblages and on a single fungal species, Aspergillus versicolor (Table 1). ROS generation and oxidative stress were not specifically examined in all studied species and cell cultures; however, marks of oxidative damage were found in B. subtilis var. niger, E. coli and $P$. fluorescens cells. The incubation time ranged from several minutes to 250 days and the effective toxic dose of nanoiron varied from $5 \mathrm{mg} \mathrm{L}^{-1}$ to $1 \mathrm{~g} \mathrm{~L}^{-1}$. The toxic response is difficult to compare because physicochemical parameters varied in each of the tested cultures or microcosms. For example, the toxic dose was different for aerated and non-aerated cultures of $E$. coli $(64,67)$. Under air saturation, nZVI was oxidized by oxygen and caused less harm than non-aerated culture. In some experiments, nZVI caused only slightly lowered cell viability (about 20\%); however, this was assessed in Table 1 as a toxic effect. The potential of nZVI to generate ROS and oxidative stress depends on nanoiron coating, mobility, size, aggregation, physico-chemical parameters and a range of other factors, such as the concentrations of organic matter or dissolved salts in the testing environment. When evaluating and comparing toxic responses it might help to normalize the observed effects through measurements of the cellular uptake of nanoparticles or $\mathrm{Fe}^{2+}$ and the state of agglomeration and oxidation of nZVI.

It is clear that nZVI effects might vary with differences in particle size. Nanoparticles below $30 \mathrm{~nm}$ have an exponentially increasing number of atoms on their surface and thus show significant differences in physico-chemical properties with changes in size (6). Interestingly, when using the surface area as a dose metric, some types of nanoparticles (e.g., $\left.\mathrm{TiO}_{2}\right)$ do not show size-dependent effects on organisms, while other nanoparticles do (e.g., $\mathrm{Ag}^{0}, \mathrm{CeO}_{2}$ ) (6). Such studies have not been performed with nZVI yet, which highlights how little is known about the biological importance of particle size. Further, in physiological and environmentally relevant media, uncoated nZVI rapidly aggregates so as to mask the true relationship between their nanosize-dependent properties and effects on organisms.

In spite of the documented potential of nZVI to create oxidative stress in various microorganisms, there are currently no scenarios depicting this effect as a significant environmental problem. Long-term experiments have shown that
nZVI effects on bacterial communities are transitory and most significant during the first hours or days $(8,56)$. The number and diversity of viable bacterial cells decreased, but was able to recover within a relatively short time. Moreover, nZVI treatment favored Archaea, probably due to increased hydrogen concentration and reducing conditions. Eubacterial abundance was maintained and diversity increased, even though the abundance of some groups decreased (56). Bacteria are extremely resilient organisms and take advantage of any niches found in the changing environment; however, little is known about nZVI effects on cyanobacteria, algae, fungi and other microorganisms such as protozoa. It is therefore likely that nZVI may cause oxidative damage to other microorganisms. The importance of such damage and the capacity of different groups of organisms to recover, both with respect to function and diversity, should therefore be examined.

\section{Acknowledgements}

This review was partially supported by the Czech Ministry of Education (1M0554).

\section{References}

1. Aguirre, J., M. Rios-Momberg, D. Hewitt, and W. Hansberg. 2005. Reactive oxygen species and development in microbial eukaryotes. Trends Microbiol. 13:111-118.

2. An, Y., T. Li, Z. Jin, M. Dong, H. Xia, and X. Wang. 2010. Effect of bimetallic and polymer-coated Fe nanoparticles on biological denitrification. Bioresour. Technol. 101:9825-9828.

3. Asada, K. 1999. The water-water cycle in chloroplasts: Scavenging of active oxygens and dissipation of excess photons. Annu. Rev. Plant Physiol. Plant Mol. Biol. 50:601-639.

4. Asada, K. 2006. Production and scavenging of reactive oxygen species in chloroplasts and their functions. Plant Physiol. 141:391396.

5. Auffan, M.l., W. Achouak, J. Rose, M.-A. Roncato, C. Chaneìac, D.T. Waite, A. Masion, J.C. Woicik, M.R. Wiesner, and J.-Y. Bottero. 2008. Relation between the Redox state of iron-based nanoparticles and their cytotoxicity toward Escherichia coli. Environ. Sci. Technol. 42:6730-6735.

6. Auffan, M.I., J. Rose, M.R. Wiesner, and J.-Y. Bottero. 2009. Chemical stability of metallic nanoparticles: A parameter controlling their potential cellular toxicity in vitro. Environ. Pollut. 157:11271133 .

7. Barnes, R.J., O. Riba, M.N. Gardner, A.C. Singer, S.A. Jackman, and I.P. Thompson. 2010. Inhibition of biological TCE and sulphate reduction in the presence of iron nanoparticles. Chemosphere $80: 554-562$.

8. Barnes, R.J., C.J. van der Gast, O. Riba, L.E. Lehtovirta, J.I. Prosser, P.J. Dobson, and I.P. Thompson. 2010. The impact of zero-valent iron nanoparticles on a river water bacterial community. J. Hazard. Mater. 184:73-80.

9. Braun, V. 1998. Regulation of iron uptake minimizes iron-mediated oxidative stress. J. Biosci. 23:483-489.

10. Breimer, L.H., and T. Lindahl. 1984. Excision of oxidized thymine from DNA. J. Biol. Chem. 259:5543-5548.

11. Cannio, R., G. Fiorentino, A. Morana, M. Rossi, and S. Bartolucci. 2000. Oxygen: friend or foe? Archaeal supeoxide dismutases in the protection of intra- and extracellular oxidative stress. Front. Biosci. 5:768-779.

12. Cano-Dominguez, N., K. Alvarez-Delfin, W. Hansberg, and J. Aguirre. 2008. NADPH oxidases NOX-1 and NOX-2 require the regulatory subunit NOR-1 to control cell differentiation and growth in Neurospora crassa. Eukaryotic Cell 7:1352-1361.

13. Clauditz, A., A. Resch, K.P. Wieland, A. Peschel, and F. Gotz. 2006. Staphyloxanthin plays a role in the fitness of Staphylococcus aureus and its ability to cope with oxidative stress. Infect. Immun. 74:49504953. 
14. Crawford, D.R., C.A. Edbauernechamen, C.V. Lowry, S.L. Salmon, Y.K. Kim, J.M.S. Davies, and K.J.A. Davies. 1994. Assessing gene-expression during oxidative stress. Methods Enzymol. 234:175-217.

15. Černík, M. 2006. Utilization of zero-valent iron nanoparticles for contaminant reduction in-situ. Habilitation thesis. Technical University of Liberec, Liberec, Czech Republic (In Czech).

16. D'Autréaux, B., and M.B. Toledano. 2007. ROS as signalling molecules: mechanisms that generate specificity in ROS homeostasis. Nat. Rev. Mol. Cell Biol. 8:813-824.

17. Dakin, H.D. 1908. The oxidation of leucin, a-amidoisovaleric acid and of a-amido-n-valeric acid with hydrogen peroxide. J. Biol. Chem. 4:63-76.

18. Dakin, H.D., and M.D. Herter. 1907. On the production of phenolic acids by the oxidation with hydrogen peroxide of the ammonium salts of benzoic acid and its derivatives, with some remarks on the mode of formation of phenolic substances in the organism. J. Biol. Chem. 3:419-434.

19. Davies, K.J. 2000. Oxidative stress, antioxidant defenses, and damage removal, repair, and replacement systems. IUBMB Life 50:279-289.

20. Dean, R.T., S. Fu, R. Stocker, and M.J. Davies. 1997. Biochemistry and pathology of radical-mediated protein oxidation. Biochem. $\mathrm{J}$. 324:1-18.

21. Demple, B., and S. Linn. 1982. 5,6-Saturated thymine lesions in DNA: production by ultraviolet light or hydrogen peroxide. Nucleic Acids Res. 10:3781-3789.

22. Diao, M., and M. Yao. 2009. Use of zero-valent iron nanoparticles in inactivating microbes. Water Res. 43:5243-5251.

23. El-Temsah, Y.S., and E.J. Joner. 2011. Impact of $\mathrm{Fe}$ and $\mathrm{Ag}$ nanoparticles on seed germination and differences in bioavailability during exposure in aqueous suspension and soil. Environ. Toxicol. doi: $10.1002 /$ tox. 20610 .

24. Elliott, D.W., and W.X. Zhang. 2001. Field assessment of nanoscale biometallic particles for groundwater treatment. Environ. Sci. Technol. 35:4922-4926.

25. Estevez, M.S., G. Malanga, and S. Puntarulo. 2001. Iron-dependent oxidative stress in Chlorella vulgaris. Plant Sci. 161:9-17.

26. Farr, S.B., and T. Kogoma. 1991. Oxidative stress responses in Escherichia coli and Salmonella typhimurium. Microbiol. Rev. 55:561-585.

27. Fenton, H.J.H. 1894. Oxidation of tartaric acid in presence of iron. J. Chem. Soc., Trans. 65:899-910.

28. Filip, J., R. Zboril, O. Schneeweiss, J. Zeman, M. Cernik, P. Kvapil, and M. Otyepka. 2007. Environmental applications of chemically pure natural ferrihydrite. Environ. Sci. Technol. 41:4367-4374.

29. Finkel, T. 2003. Oxidant signals and oxidative stress. Curr. Opin. Cell Biol. 15:247-254

30. Flint, D.H., J.F. Tuminello, and M.H. Emptage. 1993. The inactivation of $\mathrm{Fe}-\mathrm{S}$ cluster containing hydro-lyases by superoxide. J. Biol. Chem. 268:22369-22376.

31. Fridovich, I. 1978. Superoxide radicals, superoxide dismutases and the aerobic lifestyle. Photochem. Photobiol. 28:733-741.

32. Ghauch, A., A. Tuqan, and H.A. Assi. 2009. Antibiotic removal from water: Elimination of amoxicillin and ampicillin by microscale and nanoscale iron particles. Environ. Pollut. 157:1626-1635.

33. Ghosal, D., M. Omelchenko, E. Gaidamakova, et al. 2005. How radiation kills cells: Survival of and under oxidative stress. FEMS Microbiol. Rev. 29:361-375.

34. Gusarov, I. 2005. NO-mediated cytoprotection: Instant adaptation to oxidative stress in bacteria. Proc. Natl. Acad. Sci. U.S.A. 102:13855-13860.

35. Gutteridge, J.M.C., S.K. Paterson, A.W. Segal, and B. Halliwell 1981. Inhibition of lipid-peroxidation by the iron-binding protein lactoferrin. Biochem. J. 199:259-261.

36. Haber, F., and J. Weiss. 1934. The catalytic decomposition of hydrogen peroxide by iron salts. Proc. R. Soc. London, Ser. A. 147:332-351.

37. Halliwell, B., and S. Chirico. 1993. Lipid peroxidation: its mechanism, measurement, and significance. Am. J. Clin. Nutr. $57: 7155-7245$
38. He, F., M. Zhang, T.W. Qian, and D.Y. Zhao. 2009. Transport of carboxymethyl cellulose stabilized iron nanoparticles in porous media: Column experiments and modeling. J. Colloid Interface Sci. 334:96-102.

39. He, F., D.Y. Zhao, and C. Paul. 2010. Field assessment of carboxymethyl cellulose stabilized iron nanoparticles for in situ destruction of chlorinated solvents in source zones. Water Res. 44:2360-2370.

40. Henle, E.S., and S. Linn. 1997. Formation, prevention, and repair of DNA damage by iron/hydrogen peroxide. J. Biol. Chem. 272:19095-19098.

41. Horsburgh, M.J., M.O. Clements, H. Crossley, E. Ingham, and S.J. Foster. 2001. PerR controls oxidative stress resistance and iron storage proteins and is required for virulence in Staphylococcus aureus. Infect. Immun. 69:3744-3754.

42. Christman, M.F., R.W. Morgan, F.S. Jacobson, and B.N. Ames. 1985. Positive control of a regulon for defenses against oxidative stress and some heat-shock proteins in Salmonella typhimurium. Cell 41:753-762.

43. Imlay, J.A., and I. Fridovich. 1991. Superoxide production by respiring membranes of Escherichia coli. Free Radical Res. Commun. 12-3:59-66

44. Imlay, J.A., S.M. Chin, and S. Linn. 1988. Toxic DNA damage by hydrogen peroxide through the Fenton reaction in vivo and in vitro. Science 240:640-642.

45. Itou, Y., S. Okada, and M. Murakami. 2001. Two structural isomeric siderophores from the freshwater cyanobacterium Anabaena cylindrica (NIES-19). Tetrahedron 57:9093-9099.

46. Janknegt, P.J., W.H. van de Poll, R.J.W. Visser, J.W. Rijstenbil, and A.G.J. Buma. 2008. Oxidative stress responses in the marine antarctic diatom Chaetoceros brevis (Bacillariophyceae) during photoacclimation. J. Phycol. 44:957-966.

47. Johnstone, C., J. Day, H. Staines, and E. Benson. 2006. An in vitro oxidative stress test for determining pollutant tolerance in algae. Ecol. Indic. 6:770-779.

48. Jornot, L., H. Petersen, and A.F. Junod. 1998. Hydrogen peroxideinduced DNA damage is independent of nuclear calcium but dependent on redox-active ions. Biochem. J. 335:85-94.

49. Kádár, E., D.M. Lowe, M. Solé, A.S. Fisher, A.N. Jha, J.W. Readman, and T.H. Hutchinson. 2009. Uptake and biological responses to nano-Fe versus soluble $\mathrm{FeCl}_{3}$ in excised mussel gills. Anal. Bioanal. Chem. 396:657-666.

50. Kawakami, S.K., M. Gledhill, and E.P. Achterberg. 2006. Production of phytochelatins and glutathione by marine phytoplankton in response to metal stress. J. Phycol. 42:975-989.

51. Keenan, C.R., and D.L. Sedlak. 2008. Factors affecting the yield of oxidants from the reaction of nanoparticulate zero-valent iron and oxygen. Environ. Sci. Technol. 42:1262-1267.

52. Keenan, C.R., R. Goth-Goldstein, D. Lucas, and D.L. Sedlak. 2009 Oxidative stress induced by zero-valent iron nanoparticles and $\mathrm{Fe}(\mathrm{II})$ in human bronchial epithelial cells. Environ. Sci. Technol. 43:45554560 .

53. Keyer, K., and J.A. Imlay. 1996. Superoxide accelerates DNA damage by elevating free-iron levels. Proc. Natl. Acad. Sci. U.S.A 93:13635-13640.

54. Kim, H.-J., T. Phenrat, R.D. Tilton, and G.V. Lowry. 2009. Fe0 nanoparticles remain mobile in porous media after aging due to slow desorption of polymeric surface modifiers. Environ. Sci. Technol. 43:3824-3830.

55. Kirk, G.J.D. 2004. The biochemistry of submerged soils. John Wiley and Sons, Ltd., Chichester, U.K.

56. Kirschling, T.L., K.B. Gregory, E.G. Minkley, G.V. Lowry, and R.D. Tilton. 2010. Impact of nanoscale zero valent iron on geochemistry and microbial populations in trichloroethylene contaminated aquifer materials. Environ. Sci. Technol. 44:3474-3480.

57. Kitayama, K., M. Kitayama, T. Osafune, and R.K. Togasaki. 1999. Subcellular localization of iron and manganese superoxide dismutase in Chlamydomonas reinhardtii (Chlorophyceae). J. Phycol. 35:136-142.

58. Klaine, S.J., P.J.J. Alvarez, G.E. Batley, T.F. Fernandes, R.D. Handy, D.Y. Lyon, S. Mahendra, M.J. McLaughlin, and J.R. Lead. 2008. Nanomaterials in the environment: behavior, fate, bioavailability, and effects. Environ. Toxicol. Chem. 27:1825-1851. 
59. Klimkova, S., M. Cernik, L. Lacinova, J. Filip, D. Jancik, and R. Zboril. 2011. Zero-valent iron nanoparticles in treatment of acid mine water from in situ uranium leaching. Chemosphere. 82:11781184.

60. Knauer, K., B. Ahner, H.B. Xue, and L. Sigg. 1998. Metal and phytochelatin content in phytoplankton from freshwater lakes with different metal concentrations. Environ. Toxicol. Chem. 17:24442452.

61. Kobayashi, M., T. Kakizono, and S. Nagai. 1993. Enhanced carotenoid biosynthesis by oxidative stress in acetate-induced cyst cells of a green unicellular alga, Haematococcus pluviali. Appl. Environ. Microbiol. 59:867-873.

62. Lacinova, L., P. Kvapil, and M. Cernik. 2011. A field comparison of two reductive dechlorination (NZVI and lactate) methods. Environ. Technol. doi: 10.1080/09593330.2011.592225.

63. Ledford, H.K., and K.K. Niyogi. 2005. Singlet oxygen and photooxidative stress management in plants and algae. Plant Cell Environ. 28:1037-1045

64. Lee, C., J.Y. Kim, W.I. Lee, K.L. Nelson, J. Yoon, and D.L. Sedlak. 2008. Bactericidal effect of zero-valent iron nanoparticles on Escherichia coli. Environ. Sci. Technol. 42:4927-4933.

65. Li, X.Q., D.W. Elliott, and W.X. Zhang. 2006. Zero-valent iron nanoparticles for abatement of environmental pollutants: Materials and engineering aspects. Crit. Rev. Solid State Mater. Sci. 31:111122.

66. Li, Y., M. Sommerfeld, F. Chen, and Q. Hu. 2008. Consumption of oxygen by astaxanthin biosynthesis: A protective mechanism against oxidative stress in Haematococcus pluvialis (Chlorophyceae). J. Plant Physiol. 165:1783-1797.

67. Li, Z.Q., K. Greden, P.J.J. Alvarez, K.B. Gregory, and G.V. Lowry. 2010. Adsorbed polymer and NOM limits adhesion and toxicity of nano scale zerovalent iron to E. coli. Environ. Sci. Technol. 44:3462-3467.

68. Limbach, L.K., P. Wick, P. Manser, R.N. Grass, A. Bruinink, and W.J. Stark. 2007. Exposure of engineered nanoparticles to human lung cells: influence of chemical composition and catalytic activity on oxidative stress. Environ. Sci. Technol. 41:4158-4163.

69. Limbach, L.K., R.N. Grass, and W.J. Stark. 2009. Physico-chemical differences between particle- and molecule-derived toxicity: Can we make inherently safe nanoparticles? Chimia 63:38-43.

70. Lin, Y.H., H.H. Tseng, M.Y. Wey, and M.D. Lin. 2010 Characteristics of two types of stabilized nano zero-valent iron and transport in porous media. Sci. Total Environ. 408:2260-2267.

71. Luo, Y., E.S. Henle, R. Chatopadhyaya, R. Jin, and S. Linn. 1994. Detecting DNA damage caused by iron and hydrogen peroxide. Methods Enzymol. 234:51-59.

72. Lushchak, V.I. 2001. Oxidative stress and mechanisms of protection against it in bacteria. Biochemistry (Moscow). 66:476-489.

73. Mallick, N., and F.H. Mohn. 2000. Reactive oxygen species: response of algal cells. J. Plant Physiol. 157:183-193.

74. Martin, J.E., A.A. Herzing, W.L. Yan, X.Q. Li, B.E. Koel, C.J. Kiely, and W.X. Zhang. 2008. Determination of the oxide layer thickness in core-shell zerovalent iron nanoparticles. Langmuir. 24:4329-4334.

75. Martinez, A., and R. Kolter. 1997. Protection of DNA during oxidative stress by the nonspecific DNA-binding protein Dps. J. Bacteriol. 179:5188-5194.

76. Mate, M.J., M. Zamocky, L.M. Nykyri, C. Herzog, P.M. Alzari, C. Betzel, F. Koller, and I. Fita. 1999. Structure of catalase-A from Saccharomyces cerevisiae. J. Mol. Biol. 286:135-149.

77. Meng, H., T. Xia, S. George, and A.E. Nel. 2009. A Predictive Toxicological Paradigm for the Safety Assessment of Nanomaterials. ACS Nano. 3:1620-1627.

78. Morikawa, K., R.L. Ohniwa, T. Ohta, Y. Tanaka, K. Takeyasu, and T. Msadek. 2010. Adaptation beyond the stress response: Cell structure dynamics and population heterogeneity in Staphylococcus aureus. Microbes Environ. 25:75-82.

79. Navarro, E., A. Baun, R. Behra, N.B. Hartmann, J. Filser, A.-J. Miao, A. Quigg, P.H. Santschi, and L. Sigg. 2008. Environmental behavior and ecotoxicity of engineered nanoparticles to algae, plants, and fungi. Ecotoxicology 17:372-386.

80. Nohl, H., L. Gille, and K. Staniek. 2005. Intracellular generation of reactive oxygen species by mitochondria. Biochem. Pharmacol. 69:719-723.
81. Park, S., and J.A. Imlay. 2003. High levels of intracellular cysteine promote oxidative DNA damage by driving the Fenton reaction. J. Bacteriol. 185:1942-1950.

82. Phenrat, T., N. Saleh, K. Sirk, H.J. Kim, R.D. Tilton, and G.V. Lowry. 2008. Stabilization of aqueous nanoscale zerovalent iron dispersions by anionic polyelectrolytes: adsorbed anionic polyelectrolyte layer properties and their effect on aggregation and sedimentation. J. Nanopart. Res. 10:795-814.

83. Phenrat, T., H.-J. Kim, F. Fagerlund, T. Illangasekare, and G.V. Lowry. 2010. Empirical correlations to estimate agglomerate size and deposition during injection of a polyelectrolyte-modified $\mathrm{Fe} 0$ nanoparticle at high particle concentration in saturated sand. J. Contam. Hydrol. 118:152-164.

84. Pinto, E., T.C.S. Sigaud-Kutner, M.A.S. Leitao, O. Okamoto, D. Morse, and P. Colepicolo. 2003. Heavy metal-induced oxidative stress in algae. J. Phycol. 39:1008-1018.

85. Ponder, S.M., J.G. Darab, and T.E. Mallouk. 2000. Remediation of $\mathrm{Cr}(\mathrm{VI})$ and $\mathrm{Pb}(\mathrm{II})$ aqueous solutions using supported, nanoscale zero-valent iron. Environ. Sci. Technol. 34:2564-2569.

86. Ramsay, B., B. Wiedenheft, M. Allen, G.H. Gauss, C.M. Lawrence, M. Young, and T. Douglas. 2006. Dps-like protein from the hyperthermophilic archaeon Pyrococcus furiosus. J. Inorg. Biochem. 100:1061-1068.

87. Raychoudhury, T., G. Naja, and S. Ghoshal. 2010. Assessment of transport of two polyelectrolyte-stabilized zero-valent iron nanoparticles in porous media. J. Contam. Hydrol. 170:482-491.

88. Reif, D.W. 1992. Ferritin as a source of iron for oxidative damage. Free Radical Biol. Med. 12:417-427.

89. Rowe, L.A. 2009. DNA damage-induced reactive oxygen species: A genotoxic stress response. Ph.D. thesis. Emory University, Atlanta, U.S.A.

90. Saleh, N., H.-J. Kim, T. Phenrat, K. Matyjaszewski, R.D. Tilton, and G.V. Lowry. 2008. Ionic strength and composition affect the mobility of surface-modified $\mathrm{Fe} 0$ nanoparticles in water-saturated sand columns. Environ. Sci. Technol. 42:3349-3355.

91. Schulze, E., J.T.J. Ferrucci, K. Poss, L. Lapointe, A. Bogdanova, and R. Weissleder. 1995. Cellular uptake and trafficking of a prototypical magnetic iron oxide label in vitro. Invest. Radiol. 30:604-610

92. Schützendübel, A., and A. Polle. 2002. Plant responses to abiotic stresses: heavy metal-induced oxidative stress and protection by mycorrhization. J. Exp. Bot. 53:1351-1365.

93. Smith, S.E., E. Facelli, S. Pope, and F.A. Smith. 2010. Plant performance in stressful environments: interpreting new and established knowledge of the roles of arbuscular mycorrhizas. Plant Soil. 326:3-20.

94. Søballe, B., and R.K. Poole. 2000. Ubiquinone limits oxidative stress in Escherichia coli. Microbiology 146:787-796.

95. Spuhler, D., J.A. Rengifo-Herrera, and C. Pulgarin. 2010. The effect of $\mathrm{Fe}^{2+}, \mathrm{Fe}^{3+}, \mathrm{H}_{2} \mathrm{O}_{2}$ and the photo-Fenton reagent at near neutral $\mathrm{pH}$ on the solar disinfection (SODIS) at low temperatures of water containing Escherichia coli K12. Appl. Catal. B. 96:126-141.

96. Stadtman, E.R., and C.N. Oliver. 1991. Metal-catalyzed oxidation of proteins. J. Biol. Chem. 266:2005-2008.

97. Stumm, W., and J.J. Morgan. 1996. Aquatic Chemistry, Chemical Equilibria and Rates in Natural Waters. John Wiley and Sons, Inc., New York, U.S.A.

98. Szivák, I., R. Behra, and L. Sigg. 2009. Metal-induced reactive oxygen species production in Chlamydomonas reinhardtii (Chlorophyceae). J. Phycol. 45:427-435.

99. Tappel, A.L. 1973. Lipid peroxidation damage to cell components. Fed. Proc. 32:1870-1874.

100. Thammavongs, B., E. Denou, G. Missous, M. Gueguen, and J.M Panoff. 2008. Response to environmental stress as a global phenomenon in biology: The example of microorganisms. Microbes Environ. 23:20-23.

101. Touati, D. 2000. Iron and oxidative stress in bacteria. Arch. Biochem. Biophys. 373(1):1-6.

102. van Vliet, A.H.M., J.M. Ketley, S.F. Park, and C.W. Penn. 2002. The role of iron in Campylobacter gene regulation, metabolism and oxidative stress defense. FEMS Microbiol. Rev. 26:173-186. 
103. Wang, Y., P.C. Leung, P. Qian, and J.-D. Gu. 2004. Effect of UV, $\mathrm{H}_{2} \mathrm{O}_{2}$ and $\mathrm{Fe}^{3+}$ on the growth of four environmental isolates of Aeromonas and Vibrio species from a mangrove environment. Microbes Environ. 19:163-171.

104. Wang, S.W., C.Y. Chen, J.T. Tseng, S.H. Liang, S.C. Chen, C. Hsieh, Y.H. Chen, and C.C. Chen. 2009. Orf4 of the Bacillus cereus sigB gene cluster encodes a general stress-inducible Dps-like bacterioferritin. J. Bacteriol. 191:4522-4533.

105. Wei, Y.-T., S.-C. Wu, C.-M. Chou, C.-H. Che, S.-M. Tsai, and H.-L. Lien. 2010. Influence of nanoscale zero-valent iron on geochemical properties of groundwater and vinyl chloride degradation: A field case study. Water Res. 44:131-140.

106. Wilhelm, C., C. Billotey, J. Roger, J.N. Pons, J.-C. Bacri, and F. Gazeau. 2003. Intracellular uptake of anionic superparamagnetic nanoparticles as a function of their surface coating. Biomaterials. 24:1001-1011.

107. Wolfe-Simon, F., D. Grzebyk, O. Schofield, and P.G. Falkowski. 2005. The role and evolution of superoxide dismutases in algae. J. Phycol. 41:453-465.

108. Wooldridge, K.G., and P.H. Williams. 1993. Iron uptake mechanisms of pathogenic bacteria. FEMS Microbiol. Rev. 12:325-348.
109. Xia, T., M. Kovochich, M. Liong, L. Madler, B. Gilbert, H.B. Shi, J.I. Yeh, J.I. Zink, and A.E. Nel. 2008. Comparison of the mechanism of toxicity of zinc oxide and cerium oxide nanoparticles based on dissolution and oxidative stress properties. ACS Nano. 2:2121-2134.

110. Xiu, Z.M., Z.H. Jin, T.L. Li, S. Mahendra, G.V. Lowry, and P.J.J. Alvarez. 2010. Effects of nano-scale zero-valent iron particles on a mixed culture dechlorinating trichloroethylene. Bioresour. Technol. 101:1141-1146.

111. Yoon, A.J., J.E. Park, J.-H. Yang, and J.W. Park. 2002. OxyR regulon controls lipid peroxidation-mediated oxidative stress in Escherichia coli. J. Biochem. Mol. Biol. 35:297-301.

112. Zhang, W.X. 2003. Nanoscale iron particles for environmental remediation: An overview. J. Nanopart. Res. 5:323-332.

113. Zorov, D.B., C.R. Filburn, L.O. Klotz, J.L. Zweier, and S.J. Sollott. 2000. Reactive oxygen species (ROS)-induced ROS release: A new phenomenon accompanying induction of the mitochondrial permeability transition in cardiac myocytes. J. Exp. Med. 192:1001-1014.

114. Zorov, D.B., M. Juhaszova, and S.J. Sollott. 2006. Mitochondrial ROS-induced ROS release: An update and review. Biochim. Biophys. Acta, Bioenerg. 1757:509-517. 